\title{
Nepal's West Seti Project Imbroglio: The Supreme Court Speaks
}

\author{
Kishor Uprety \\ Attorney at Law, Nepal. \\ Email: aastha7@cox.net \\ Received January $4^{\text {th }}$, 2011; revised January $13^{\text {th }}, 2011$; accepted February $1^{\text {st }}, 2011$.
}

\begin{abstract}
The history of Indo-Nepal water resource cooperation is a litany of dashed hopes, shelved projects, treaties lacking implementation, and mutual recrimination. The small-neighbor versus big-brother syndrome that pervades relations in every sphere invariably arouses suspicion of unequal benefits. In this context the West Seti Hydroelectric Project in far western Nepal, the biggest energy generation project, was also stymied for more than a decade. This Project's fate was put on balance with a non-governmental organization moving the Supreme Court, alleging the Project would help India at Nepal's expense, and asking the Court to stop it since it was "illegal" and went against "national interests". The Court's ruling, touching broadly upon the issues of national, international, and environmental laws, established a precedent of significant value which will impact if not reshape the nature of cooperative development in the region.
\end{abstract}

Keywords: Hydro-Power, Development, International and Environmental Law, Riparian Rights

\section{Background}

A government decision to build a multi-billion dollars hydropower project on the Seti River in the far western region of Nepal (West Seti Hydroelectric Project or "Project") became a much discussed topic in the country, especially, during 2006-2008. The Project, aimed at producing power primarily for export to India, involved the construction of a high dam, storing of excess wet season river flows in its reservoir, and using of water to generate electrical energy during peak demand periods in the dry season [1]. The resulting reservoir, developments downstream of the dam, and the transmission lines running from the Project site, would also inundate over 2000 hectares of land and affect 18,269 people in 2,421 households, and requiring resettlement of an estimated 1,393 of those households.

The private and public entities financing the Project, namely the Snowy Mountains Engineering Company

\footnotetext{
${ }^{1}$ It was not possible, however, at the time to determine the real price that was being paid to accomplish that. According to a senior analyst, this was because the environmental impact assessment (EIA) prepared by SMEC-WSHL, and approved by GON as a prerequisite for the approval of the Project, failed to address certain major issues about the economic and environmental costs. Those omissions in the EIA related to its failure to take climate change into account, the Project's economic returns for investors and Nepal, and its environmental and social consequences. For a more detailed discussion, see [3].
}

(SMEC), an Australian Corporation, the West Seti Hydroelectric Corporation Limited (WSHL), the government of Nepal (GON), and the Asian Development Bank (ADB) considered the Project-related decision a way of enabling Nepal to generate much-needed revenue from the use of its rich water resources, and a means of enabling India to meet its energy needs in a climate-friendly manner. ${ }^{1}$ Opponents, however, viewed that, in light of the severe and long-term consequences of developing such a major dam project, which will irreversibly destroy ecosystems, permanently alter land and water use in the area, necessitate resettlement of a huge number of people, and require huge investments from government and private funds, the venture called for full disclosure and discussion of its detailed costs and benefits.

\section{The Contractual Framework}

In 1994, GON concluded an agreement with the SMEC to explore the development of the Project. Among other, the 1994 agreement provided that SMEC, through a subsidiary company it established under the laws of Nepal (the WSHL) would initiate work to prepare a Detailed Engineering Report (DER) on the Project. In 1997, the agreement between SMEC and GON was renewed along with additional amendments. The amendment, among others, increased the capacity of the Project from 360 
MW, as originally envisaged, to $750 \mathrm{MW}[2] .^{2}$ That same year, in May, a Power Purchase Agreement (PPA) was reached in connection with the export of electricity from the proposed Project; and in June a Project Agreement was concluded setting forth the detailed terms and conditions for proceeding with the implementation of the Project.

The export of electricity will, therefore, be undertaken within the framework of the PPA between SMEC-WSHL and Power Trading Company India Limited (PTC). PTC, in turn, will sell power within the Northern region of India. The tariff, expected to be on a take-or-pay basis, will comprise 1) off-peak energy rate, 2) peak energy rate, and 3) excess energy rate. The average tariff will be $\$ 0.04 .95 /$ kilowatt-hour at the point of delivery on the Nepal-India border.

The 1997 Project Agreement between WSHL and GON stated that SMEC-WSHL would prepare an Environmental Impact Assessment (EIA) of the Project as part of the DER, in accordance with the National Environmental Impact Assessment Guidelines, 2050, the Environment Protection Act, 2053 and all relevant rules and guidelines made thereunder. SMEC-WSHL submitted the DER to the government in December 1997, and received approval in January 1999. Subsequently in August 1999, SMEC-WSHL submitted an EIA, and in 2000, Nepal's relevant agency approved the Project. In 2007, SMECWSHL updated the EIA along with information on the impacts of the transmission line and incorporating new considerations on increased costs and the plan to resettle people affected by the Project. ${ }^{3}$

Under the terms of the Project Agreement, the Government receives revenue from the sale of power through energy and capacity royalties. In addition, the Government was given an option to receive $10 \%$ of the output of the power station as free power, or $10 \%$ of the revenue

\footnotetext{
${ }^{2}$ It is important to note that, after this date also, the agreement has been amended eight times already (11 December 1998, 5 November 1999, 20 June 2001, 7 May 2002, 8 January 2004, 8 February 2005, 1 march 2006, and 29 October 2006). The 29 October 2006 amendment (the 8th amendment) modified article 16.6 and included a provision that SMEC would pay GON a $0.05 \%$ export tax. In the earlier versions, this percentage was missing. At the same time, by amending article 18.1, the two parties included a provision that GON would receive $10 \%$ of the net income of the sales of the power. The amendment does not state that Nepal would receive $10 \%$ electricity free of cost (unlike reports by the media which actually covered this aspect in an ambiguous fashion). Anyway, despite 8 amendments, the royalty of $2 \%$ fixed as per the Electricity Act of 1992 still applies, although the new water resource policy specifies that such royalties be set at $12 \%$. For detail, see Dixit 2008 : 158-159.

${ }^{3}$ As stated in the EIA, the Project involves construction of a 195 meter-high concrete-faced rock-fill dam, creating a 2,060-hectare reservoir area with a total storage capacity of 1,566 million cubic meters of water, and will require the acquisition of 2,326 hectares of land, including 659 hectares of cultivated land, 806 hectares of forest, 246 hectares of grassland and 169 acres of shrub land.
}

received under the terms of the PPA, in lieu of free power. The government chose the latter option. ${ }^{4}$ Nevertheless, some experts say that after 14 years of the agreement, the real figure of royalty is still not clear [2].

The Project is a build-own-operate-transfer scheme, for which WSHL has a 30-year license to generate for 24.5 years. The PPA has a 25-year term from the date the Project starts commercial operation, at the end of which period, full ownership will be transferred to GON.

The dam site is located on the Seti River, $82 \mathrm{~km}$ upstream of the confluence of the Seti and Karnali rivers. The Project sites, in the middle mountains, at elevations ranging from 550 to 920 meters, span six districts. All sites, excluding the reservoir area and transmission line corridor, are located in Doti and/or Dadeldhura districts. The reservoir is located in Baitadi and Bajhang districts, and the transmission line corridor crosses the districts of Doti, Dadeldhura, Kailali, and Kanchanpur.

The plant consists of four Francis-type vertical-shaft turbines connected to four alternators, each with an output of 187.5 MW at the rated net head. The average annual electricity production will total about 3,636 gigawatt-hours (GWh). The main Project features are a $195 \mathrm{~m}$ high concrete faced rock-fill dam, 2,060 hectare (ha) reservoir area, $6.7 \mathrm{~km}$ headrace tunnel, underground power station, $620 \mathrm{~m}$ tailrace tunnel, regulation weir, switchyard, $20.3 \mathrm{~km}$ permanent access roads, and $132.5 \mathrm{~km} 400$ kilovolt $(\mathrm{kV})$ double-circuit transmission line in Nepal, as well as permanent accommodation for up to 200 operation and maintenance staff [4].

The Project will generate power from a head of $259 \mathrm{~m}$, created by running the headrace tunnel across a river bend of the Seti River and thus diverting water around a $19.2 \mathrm{~km}$ river section. The reservoir will fill during the monsoon season (mid June to late September/early October), and then water will be drawn down to generate

\footnotetext{
${ }^{4}$ According to SMEC-WSHL's 2007 estimates, GON would receive $\$ 991$ million in revenue during the course of the 30-year generation license, with an average annual benefit of $\$ 33$ million. After the thirty-year license expires, SMEC-WSHL projects that GON would receive $\$ 170$ million per year in revenue from electricity sales to India (assuming the prices in the power purchase agreement between SMEC-WSHL and PTC continue to apply). Experts have noted that such a revenue stream, however, would only be temporary because the accumulation of sediment in the reservoir will eventually prevent WSHP from being able to generate power. It may also be noted that, according to the EIA, sedimentation in the reservoir could terminate the Project's useful life within 25 years after its transfer to the GON. At that time, the government would be required to decommission the dam, a process requiring the government to perform a host of significant tasks (assessing the safety of the dam; removing selected facilities and maintaining others; recycling and disposing of materials and wastes, including hazardous wastes; evaluating the effect of decommissioning on aquatic ecosystems and uses of the river water; identifying ways to mitigate negative effects of decommissioning; conducting ongoing maintenance, surveillance, and security of retained facilities; and budgeting for and financing these and other necessary activities. For detail, see, Johnson 2010: 515.
} 
power at peak times each day during the dry season. ${ }^{5}$ The peak generation flow will be $330 \mathrm{~m} 3 / \mathrm{s}$. The daily and seasonal pattern of power generation will be dictated by market demand. Average power generation over seven months, from November to May, is likely to be over two periods per day (to match peak power demand in India).

Power will be transmitted from the Project via a 230.5 $\mathrm{km} 400 \mathrm{kV}$ transmission line, the initial $132.5 \mathrm{~km}$ located in Nepal, running south from the switchyard to Attariya then West to Mahendranagar, and the final $98 \mathrm{~km}$ heading southwest in India to join the Indian transmission grid at Atamanda, $22 \mathrm{~km}$ north of Bareilly.

\section{Call for Court's Intervention}

In view of the significant public concern associated with the Project, a writ petition was filed at the Supreme Court of Nepal in August 2006 by seven individuals (locals and human rights activists) against a number of State institutions and the private companies (SMEC and WSHL), claiming that several issues of significance were neglected by the agreements on the West Seti Project. The petition sought the Court's intervention as follows:

1) Consistent with Article 156 of the Interim Constitution, which provides for the agreement on sharing of natural resources to be approved by a two-thirds' majority of the Legislature Parliament, the agreements related to the Project be required to be so ratified;

2) Until all agreements are duly so ratified, the works under the Project is halted;

3) The agreement between GON and SMEC, including the amendment of 29 October 2006, be quashed; and

4) Consideration is given to the adverse environmental impacts that may be caused by the Project.

The Court asked for written responses from all respondents and set a hearing date. Oral arguments then followed.

\subsection{Arguments}

The agreement was contested essentially on three grounds: the rights of people in regard to the water and the river (covering the environmental, informational and other social and cultural rights, including compensation and rehabilitation); national interest (revolving around the notion of sovereignty); and as already noted above, application the Interim Constitution.

Rights of People: According to the petitioners, the Project will cause displacement of more than 15 thousand people who have been historically part of the river. These people must have the right to first use the water, to make

\footnotetext{
${ }^{5}$ The reservoir will have a total storage capacity of 1,566 million m3 (926 million $\mathrm{m} 3$ of live storage and 640 million $\mathrm{m} 3$ of dead storage) and a drawdown range of $59 \mathrm{~m}$ (from the full supply level to minimum operating level).
}

a decision over the use of water by others, and must be consulted on any resulting plan or development in connection with water. They are the stakeholders whose free and prior informed consent needs to be secured. National and international laws clearly state that the local people have the first right over their natural resources. But, against this spirit, because of the Project, the companies will retain absolute rights over water. A guarantee of the right to use water for local people's basic needs, at least, should have been included in the Project Agreement [1]. In addition, the agreement is silent on the social and economic rights of local people, as it is on benefitssharing with them, on employment opportunity for them in the Project, or on overall cost of the Project.

In this context, it is appropriate to note that costs have been defined broadly. Beyond the initial investment, they include costs of environmental degradation, submergence of forest, and loss of cultivable land that Nepal will have to bear. According to the EIA, the Project's reservoir inundates/submerges $25.1 \mathrm{~km}$ of the Seti River and a total of $28.0 \mathrm{~km}$ of five main tributaries (Chama, Dhung, Saili, Nawaghar, and Kalanga). It further notes that the permanent Project features will require the acquisition of 659 ha cultivated land, 806 ha forest, 169 ha shrubs, 246 ha grassland, 9 ha abandoned land, 5 ha settlement, 409 ha river feat and 23 ha rock/cliffs totaling 2,326 ha of land. Similarly, 678 ha will be utilized for the transmission line right-of-way. In total the Project will use 3004 ha land permanently. Although the acquisition of land, as such, is covered by the EIA report, the Project proponents have plans on the anvil to rehabilitate the displaced people by providing "land" in lieu of "cultivated land". The land occupied/cultivated by the displaced populace is just 659 ha of cultivated land, comprising $22 \%$ of total land to be acquired. In this manner, the Project will be using $\mathrm{Ne}$ pal's additional land for the purposes of rehabilitation. Moreover, the Project has no plans to provide land in lieu of remaining 2345 ha (3004 ha minus 659 ha) that it is to use. The question therefore was why Nepal should sacrifice 2345 ha land to provide low cost power to India, which will also enjoy the benefits of flood control in the rainy seasons and augmented flow in the dry season, free of charge (unjust enrichment).

The petitioners also argued that Clause 7.2(d) of the Project Agreement puts restriction on consumptive use of water in the upstream area in order to ensure the supply of water for the Project to generate electricity. ${ }^{6}$ This re-

\footnotetext{
${ }^{6}$ Clause $7.2(\mathrm{~d})$ reads: "In accordance with Rule 20 of the Electricity Regulation 2050, the Generation Licence will confer on SMEC the right of the uninterrupted flow of the West Seti River to the Project. HMGN (the Government) will not issue, and will ensure that no Government Agency issues, any other licence or permit for use of the water in the catchment area that substantially impairs the flow of such water.”
} 
striction adversely impacts a number of villages (Rayal, Dangaji, Parakatne, Bhairabnath, Chaughari, Kotbhairab, Malumela, Matela, Subeda, Luyata, Hemantabada, Chainpur, Sunkuda, Banjh, Khiratadi, Dahabagar, Pipalkot and Kapalseri in Bajhang District, Belapur in Dadeldhura District, Shivalinga, Dhungad, Sigas and Thalakada in Baitadi District, and Lamikhal, Mahadevsthan, Dahalkakikasthan, Girichauka and Chhapali in Doti District), which will not be allowed to use water for consumptive uses like irrigation. The Project undermines the significance of the issue by merely saying that there will not be any restriction on drawing of water by the people in these villages for drinking purposes, brushing aside the fact that the real issue, here, is the water for irrigation. Due to the restriction imposed by Clause 7.2(d) of the Project Agreement, no new irrigation work will be permissible in these villages. Water will also become unavailable for use by locals in the de-watered area (Bayarpada, Banlek, Jijaudamandu, Latamandu and Pachanali, in Doti District and Belapur in Dadeldhura District). The environmental flow of $10 \%$ that the Project is required to maintain will not be enough for irrigation in the villages on the banks of the dewatered river.

National and Water Sovereignty: After the construction of the dam, the volume of water will increase by 90-156 cusec. Nepal should have retained absolute rights over water stored in the dam. Nepal could have also

\footnotetext{
${ }^{7}$ The petitioners took this position relying on a number of precedents established elsewhere. According to them, the reservoir Project generates downstream benefit in terms of flood control in the rainy season, augmented flow during dry season and additional electricity generation capacity. But Nepal is deprived of any recompense for these. Note that under Article V of the Columbia Treaty between Canada and USA, the former is entitled to one half the downstream power benefits. Applying this principle to the West Seti Project, the installed capacity of which, without a reservoir, is only $100 \mathrm{MW}$, Nepal should have been entitled to power benefit of $325 \mathrm{MW}$, as its capacity increases to $750 \mathrm{MW}$ due to construction of the reservoir. The Columbia Treaty also includes a provision for (a) compensation to Canada for flood control benefit in USA (due to storage of water during rainy season), and (b) augmented flow in USA during the dry season. USA paid a lump sum to Canada for flood control as well as for the economic loss to Canada arising directly from Canada foregoing alternative uses of the storage used to provide the flood control. Under the West Seti arrangement, Nepal receives nothing for the downstream benefits that India will enjoy with the completion of the Project (India stands to receive $90 \mathrm{~m} 3 / \mathrm{s}$ during the dry season or 7.77 billion liters per day). From this perspective, India will receive a huge amount of water absolutely free. Similarly, Lesotho receives US\$ 25 million annually for $18 \mathrm{~m} 3 \mathrm{~s}$ water it supplies to South Africa. At this rate, Nepal would be entitled to US\$ 125 million per annum for the augmented flow of $90 \mathrm{~m} 3 \mathrm{~s}$ which has been sacrificed. Furthermore, analysts consider that the proponents of the Project focused on the benefit to Nepal (with a value of $\$ 1.2$ billion) that will accrue after handover of the Project, but failed to realize that it will not be worth the same (due to wear and tear). In that context, they also glossed over another serious issue of silt loads in the rivers of Nepal that are very high and within a short span of time can increase dead storages in the reservoirs. Once the reservoir gets filled up with silt, India could start asking for the decommissioning of the dam. But the Project has not allocated any fund for the purpose, meaning that Nepal will have to foot this bill. See for discussion, Shrestha (2008).
}

sought from India payment for this water. However the agreement is completely silent on the point. And, as such, it has not only ended water rights of people of Nepal; the commencement of such a practice has undermined national sovereignty. $^{7}$

Constitutional Issues: Article 156(1) of the Interim Constitution states that the ratification of, accession to, acceptance of or approval of treaties or agreements to which the State of Nepal or the Government of Nepal is to become a party shall be as determined by the law. Sub-article (2) specifies that laws to be so made shall, inter alia, require that the ratification of, accession to acceptance of or approval of treaty or agreements on (a) Peace and friendship; (b) Security and strategic alliance; (c) The boundaries of Nepal; and (d) Natural resources and the distribution of their uses, be done by a two-thirds' majority of the total number of members of the Legislature-parliament. The Constitution further provides that if any of the treaties/agreements referred to in (a) and (d) above, is of ordinary nature and does not affect the nation gravely or long term, a simple majority procedure may be followed.

According to the petitioners, the agreement for the West Seti Project establishes a regime for sharing water and electricity between Nepal and India, in addition to "giving" to India the river for 30 years. It is clearly, therefore, a case of sharing of natural resources between two countries, thus requiring a two-thirds' majority. ${ }^{8}$

\subsection{Counter Arguments}

The attorneys, on behalf of the government institutions and the two companies rebutted by making three main points:

1) SMEC-WSHL is a company registered under the Nepalese Companies Act. Providing a license to a national company is the country's internal matter. An agreement of commercial nature need not be ratified by parliament. This is not an issue concerning two countries. Only agreements between countries are subject to the

\footnotetext{
${ }^{8}$ During the $10^{\text {th }}$ modification, the Nepalese Law Ministry was also opposed to the renewal of the West Seti Agreement. It raised an objection stating that the proposal undermined the "sovereignty and integrity" of Nepal. Expressing serious concern over some of its provisions, the Minister of Law and Justice urged the Ministry of Energy not to renew the agreement without first removing one controversial clause which made Nepal government to be liable for all damages. The Ministry said "The Nepal government cannot be responsible for all the damages; it can be responsible only for damages as prescribed by Nepali law and regulations, and thus it [clause] is objectionable”. Another clause on the settlement of disputes was also considered objectionable. The agreement included English law as the applicable law for settling disputes, which the Ministry considered a serious challenge to the national sovereignty and integrity, and recommended its removal. The Ministry also objected to the Project's right to issue debentures, and asked for its removal, because no private company should have the right to issue debentures, a right only reserved for the Central Bank. See [5].
} 
constitutional provision on ratification.

2) The agreement is not an international treaty on sharing of natural resources, but an agreement warranting a license under the Electricity Act, which has been awarded after the review of the detailed environmental assessment. It concerns trading of energy (as a commodity) upon license.

3) There is no provision in the agreement specifying the quantity of water that needs to be released to India. Therefore it is not about sharing of water (natural resources). Furthermore, because the agreement will be implemented under the general oversight of the Government, the risks, if any, will be easily contained.

\subsection{The Ruling}

In the Case, the Court had five main inter-related questions to answer.

1) Whether the locus standi of petitioners is clearly established?

2) Whether the agreement is directly and indirectly against national interest, or has adversely affected downstream benefits?

3) Whether the agreement is on sharing of national natural resources, and needs to be ratified by $2 / 3$ majority of the Legislature- Parliament?

4) Whether the Project has adequately dealt with environmental issues, and has provided for adequate protection of property and wellbeing of the people living in the area? and

v) Whether an Order is warranted?

1) On the question of locus standi of the petitioners, the Court first noted that to justify a public interest, one needs to establish an obvious relation of the Project with the group, the society, the region, and the country, and substantiate that at least one has been deprived of a right.

The Project's lawyers' position was that by giving the license, a contractual relation had been established between GON and the Project. The Project-related decision was based on purely economic grounds and the contract was a technical and a commercial one. It derived from an administrative decision, and is beyond the scope of public interest.

Furthermore, the Court's jurisdictions as well as the remedies can be different on matters governed by a contract. A breach of contract, damages or benefits, comes under the Court's ordinary jurisdiction and cannot be brought within the purview of its extraordinary jurisdiction (i.e. a writ petition). GON provided a license pursuant to its sovereign right and within the framework of the law. Also, the fact that PTC is allowed to buying cheap electricity does not alone become an act against national interest, as contended by the petitioners.

The petitioners' position was that the fact that land will be inundated and livelihood affected is clear. Therefore, stating that they do not have locus would be wrong. A Project allowed to operate and to use natural resources, certainly, generates public concern because it affects human livelihood, and the decision-making related to it as well as its effects can be questioned by the general public in search of judicial remedy. Moreover, because of the scarcity of freshwater, any activity that uses water can become a matter of public interest. Water is a common good. Its values are reflected in the religions. It is also a human right, and, therefore, its use can be of public concern. ${ }^{9}$

The Court, after analyzing the arguments of both sides, at the outset, acknowledged that the Project was, no doubt, important for the country, because it brings in foreign direct investment, including skills and technology, and as such, its success or failure becomes a serious matter of concern.

The Project is located within the Nepalese territory; electricity will be generated and will be managed by a company established under the Nepalese law; after generation, water will flow, for a long distance, within the Nepalese territory, thus will not be devoid of all multipurpose uses. The Project has been selected by GON to serve its needs and its priority, along with a management mechanism also selected by it. In this connection, actually, the involvement of GON's Department of Electricity Development (DOED), particularly in the issuance of the license, is logical. Except for an agreement between PTC and SMEC-WSHC on the export of power generated from the Project, there is no other agreement in connection with this Project. There is no agreement between India and Nepal at government level.

The Court acknowledged that professional shortcomings may have been there to influence the assessment of the economic returns of investments, management of technology transfer, and understanding of the market, but nonetheless, the country's abundant natural resources and their use being indispensable to open the door for development, their exploitation also had to be started.

The Court went on to state, "It is not enough to only state that natural resources are precious; they should also be harnessed economically. That is what defines the benefits of natural resources. If we continue to sow the seeds of possibilities only, but fail to implement anything

\footnotetext{
${ }^{9}$ The petitioners also stressed the internationalized status of the right to water by making reference to, among other, the 1992 Rio de Janeiro Conference and the Agenda 21, which talk about sustainable development. They emphasized, in that context, that from selection to management of a development Project, the local people have a role to play (decision making, participation, sovereignty, benefit sharing, transparency, environmental protection, securing inter-generational right, and so forth). As a member of the UN, Nepal has a duty to abide by the UN recommendations and for the Court to order its compliance. As such, the locus standi of petitioners can be adequately established.
} 
in practice, they will never be beneficial. It is the right of the people to improve their livelihood by using natural resources. When making a decision on these types of resources, the government or its agency needs to use the law in good faith and spirit. Whether, in this context, GON's decision has undermined the peoples' rights long term, or has foreclosed their rights over these natural resources unjustly, are points that need to be considered in a different context by examining the legality of the decision. It is also important to note that in the present case, the State does not design and implement the Project itself, but with the assistance of local and foreign agencies, and a company registered in Nepal. Moreover, for the license, the State receives a royalty, receives skills and technology, receives some electricity free of cost, and after thirty years, gets the whole Project.”

The Court further stated that although divergences of views are normal, and acceptable, it is not appropriate to discredit a decision of a responsible agency about the site, the design and the management method, which has, as clearly established by the Project lawyers, carried out all necessary studies before making the choice. Certainly, on environmental issues, a careful approach is warranted, but whether the specific agreement has created a long term negative effect on the constitutional practices or national interest is something that needs to be substantiated not by guesses but by statistics, analysis, practical examples, and the assessment of the intention of the decision maker. Barring guesses and hypotheses, no information has been provided in the case on the futility of the Project. The most important point in this case is that Nepal's own agencies made a decision on the use of water resources through its own internal processes. Therefore, in the agreement related to West Seti and the natural resources involved in it, Nepal's sovereignty remains intact. The agreement is not with another country on the use and sharing of natural resources undermining national interest. ${ }^{10}$ Therefore, the petitioners' contentions are deemed baseless.

2) On the second question as to whether the agreement is directly or indirectly against national interest, or has adversely affected downstream benefits, the Court, after considering a number of principles of international law, ${ }^{11}$ made a few interesting points.

\footnotetext{
${ }^{10}$ In this context, the Court also provided the examples of Lesotho exporting water to South Africa against the payment of a royalty or Egypt building a powerhouse in Ethiopia to provide energy to Ethiopia and getting water for itself.

${ }^{11}$ It referred to the principle of absolute territorial sovereignty: that there is sovereign right of the country to use of waters from a river flowing within one's territory, and later also made reference to the UN Convention on the Law of the Non-navigational Use of International Water Resources of 1997, the principles deriving therefrom, and the elements defining equitable utilization.
}

The West Seti, not being an international river, its water being used traditionally and there being no international agreement on its governance, the right of Nepal on the unrestricted use of its waters is clear. International (or common) rivers are generally governed by agreements under international law in so far as their waters, or their use or sharing, are concerned. There are situations where lower riparian countries can abuse of the situation (weak economy, low technology and skill of upper riparians) and, by using the notion of prior use, can fulfill their own interests. But this right needs to have been established with prior agreement [6].

It is important to note that, beyond the main Project site, the Seti river continues to flow within the Nepalese territory, for a long distance, before entering another country. Yet, the upstream country cannot use it recklessly so as to affect the quantity and quality of water and to affect downstream riparian. Likewise, the downstream country also cannot use water in a manner to affect the territory and environment of the upstream country. The efforts and successes of upstream countries on water and environment protection can actually benefit downstream riparians. And, as such, it is useful for downstream countries to assist upstream countries in such endeavor. As a corollary, an upstream country also, while developing projects, should not indulge in making any unnecessary publicity that a downstream country has obtained benefits free of cost, or that it has benefited from a situation of unjust enrichment. In any case, the right to use water from a river is a right under international law. Equitable use of waters from a river is the prevailing practice, and is also "justice". It is natural for a country to use water for the benefit of its citizens. The petitioners' contention that the Project will lead to unjust enrichment is not something on which the court can give any judicial evaluation, direction or intervention.

In so far as the contract between the two companies -one registered in Nepal under Nepalese law and another in India under Indian law- is concerned, it is for the purchase of electricity, and in view of its objective and nature, it does not fall in the category of a contract creating an obligation under international law. Moreover, the Project is a fully-fledged national Project, and thus does not create any responsibility, whether directly or indirectly, under international law. There may have been some glitches in the deal emanating from the failures of diplomacy or politics involved in it, but diplomatic and political issues need to be discussed and settled in their own sphere and environment; they cannot be resolved through a judicial intervention. Also the argument of the petitioners that because the Project is financed by investments from Australia, China, India, and the ADB, there may be 
change in its "national status" is not convincing. ${ }^{12}$ Such foreign companies have not been granted any right of claim under international law

Certainly there is scarcity of serious data about the quantity of waters available in the rivers and their flow and the reduction in such quantity and flow, which may have been due to many reasons. But nobody can be held responsible for this type of change caused by the nature. In any case, in the absence of any specific agreement, concluding that some countries will derive benefits due to the Project is only a narrow suspicion and hypothetical. A judicial process cannot rely on that kind of a hypothesis.

Regarding the electricity generated and its sales in a foreign market, the Court acknowledged, at the outset, that the petitioners are not against the export of energy but have specifically questioned the low price. Nevertheless, how electricity should be supplied, or how a decision on developing a project should be made is a policy and administrative matter. The decision is incumbent upon GON's mandated agency which has to take into account factors such as investments, long-term market management, possibility of export in foreign market and so forth. Any abuse of authority by such agencies is monitored pursuant to specific applicable laws. The Court cannot, in the context of a writ petition, second guess the decision of such agency operating under the laws, and, therefore, cannot intervene.

Regarding whether the PPA has violated national Law, the Court noted that Section 35 of the Electricity Act 2049 allows the government to enter into any contract with any person or entity on generation or distribution. Similarly, Section 12 of the Water Resources Act 2049 allows the government to develop hydropower, its uses and services. The PPA, a commercial agreement, has not created any international obligations or rights under international law. On this basis, therefore, it cannot be deemed illegal and voided.

Regarding whether there is sharing of national natural resources, the Court reiterated that energy itself is not a natural resource but a commodity (or a service) deriving from a natural resource (i.e. water). All water resources, as well as the decision-making authority, after generation of electricity, still continue to remain in Nepal. The agreement is about generation/production of energy, not about sharing of water.

3) On whether the agreement needs to be ratified by a two-thirds' majority of the Legislature-Parliament, the Court relied on a content-analysis of Article 156 of the

\footnotetext{
${ }^{12}$ China joined later, in 2004. China’s state owned Export-Import Bank (China Exim Bank) agreed to extend financing of one billion US dollars for the Project, for which it signed an agreement with SMEC. The Project will be constructed by China National Machinery and Equipment Import and Export Company. For detail, see [7].
}

Interim Constitution. It reads as follows:

"156. Ratification of, Accession to, Acceptance of or Approval of Treaty or Agreements:

1) The ratification of, accession to, acceptance of or approval of treaties or agreements to which the State of Nepal or the Government of Nepal is to become a party shall be as determined by the law.

2) The laws to be made pursuant to clause (1) shall, inter alia, require that the ratification of, accession to, acceptance of or approval of treaty or agreements on the following subjects be done by a two-thirds majority of the total number of members of the Legislature-Parliament present in the House:- (a) peace and friendship; (b) security and strategic alliance; (c) the boundaries of Nepal; and (d) natural resources and the distribution of their uses.

Provided that out of the treaties and agreements referred in the subclauses (a) and (d), if any treaty or agreement is of ordinary nature and which does not affect the nation extensively, seriously or in the long-term, the ratification of, accession to, acceptance of or approval of such treaty or agreement may be done at a meeting of the Legislature-Parliament by a simple majority of the members present in the House.

3) After the commencement of the Constitution, unless a treaty or agreement is ratified, acceded, accepted or approved in accordance with this Article, it shall not be binding to the Government of Nepal or the State of Nepal.

4) Notwithstanding anything written in clauses (1) and (2), no treaty or agreement shall be concluded that may have detrimental effect on the territorial integrity of Nepal." [8].

The Court emphasized that the above constitutional provision mainly refers to the possibility of making laws to govern the treaties and agreements, or the type of majority required for their ratification. It does not spell out the different categories of agreements.

With regard to the Project, there are three sets of agreements: The agreement between GON and SMEC (for feasibility study), the agreement between GON and SMEC-WHSL (development of the Project), and the agreement between PTC and SMEC-WHSL (for power trading).

The first agreement (between GON and SMEC dated 1994), which is for feasibility only, is irrelevant for purposes of constitutional discussion. With respect to the other two agreements, the Court made two points. Article 2(a) of Treaty Act 2047, defines a treaty between countries or a country and an international organization. In similar vein, Article 2 (1) of the Vienna Convention of the law of Treaties also defines a treaty as "agreement conducted between states and governed by international 
law..." Based on these, the Court concluded that the above agreements do not fall in the category of agreements as defined by the Treaty Act. The Court further pointed out that if a different position was taken, a precedent would be created in which the country would be completely barred from developing any Project, economically beneficial or not. Therefore, the agreements do not require to be ratified by a two-thirds' majority as they are not about the sharing of natural resources, and are not international treaties, stricto sensu.

4) On whether the Project has adequately dealt with environmental issues and downstream effects and whether it has provided for adequate protection to the property and wellbeing of people living in the area, the Court acknowledged that development projects have the potential of adversely affecting environment and livelihood. The effort, therefore, should be to minimize such problems and lower and manage such risks. That is why an EIA is generally required. Our type of country, the Court noted, needs more and more development projects, and impeding development by only creating problems of environment is nonsensical. It is, on the contrary, important to participate constructively in the development of the country by creating a balance between its developmental needs and environmental concerns. The Project, being in its early stage, it is important to identify its weaknesses and mitigate environmental adverse effects. It has, indeed, been given a license to operate, which does not mean that it will, and it can, neglect all environmental concerns. The Court further stressed that only identifying is not enough; an honest and effective implementation of recommended measures is indispensable, and even though the petition failed to do so, the rare species, fauna and flora, and environmental effects on them should also be part of the solution.

Big companies generally tend to carry out EIA especially because of legal requirement, but do not present such EIA in a language understandable to all stakeholders, which often results in misunderstanding by the latter. Therefore, it is imperative to let people participate in the assessment and management of plans, and the Project needs to honestly inform the concerned stakeholders regularly and provide them with opportunities. In this context, the Court also deemed it important to develop an administrative machinery to preserve nature and protect the population through appropriate plans, and if need be, through a fund established for such purpose. The Executive Branch was asked to be proactive in establishing such a fund, and monitoring and evaluating it.

5) Finally, on whether an Order is warranted, the Court reiterated two points.

Because the agreement between GON and WSHL is not an agreement between two countries on the sharing of specific natural resources, and because the companies received a license to generate and export power, it cannot be considered an agreement for sharing of natural resources and benefits. A parliamentary ratification for the Project is, therefore, not required.

Given the fact that after thirty years, upon completion of the contract, the Project will be returned to the GON, it cannot be considered as having created adverse long term effect. The downstream water within Nepalese territory, after generation, continuing to be usable by Nepal, it cannot be considered as having limited Nepal's rights on the use of water, in any manner whatsoever. Therefore, the Court denied to issuing an Order to halt all Project related work, as per the petitioners' request.

\section{Conclusions}

On September 9, 2008, thus, the Supreme Court, through its landmark verdict, issued by Justice Anup Raj Sharma and Justice Kalyan Shrestha, upheld the West Seti deal. While so doing, as noted above, Justice Sharma and Justice Shrestha also ordered GON to develop a permanent mechanism to compensate people who will be affected by big undertakings such as this West Seti Project. In addition to displaying an exemplary environment-friendly approach, in their verdict, they have also successfully managed the ambiguity that tags along the notion of sovereignty, often a thorny item in the discourse of the Nepalese bilateral relations, by providing a clear explanation to its constructive understanding, and made of "water", no more than a simple easily tradable commodity. This verdict, needless to stress, will have a long-term and farreaching effect on Nepal's efforts to develop mega projects involving multiple national and international investors.

\section{REFERENCES}

[1] L. Johnson, “Advocacy Strategies for Promoting Greater Consideration of Climate Change and Human Rights in Development Activities: The Case of the West Seti Hydroelectric Project in Nepal,” Vol. 27, No. 2, Pace Environmental Law Review, 2010.

[2] A. Dixit, "Dui Chhimekiko Jalayatra," The Water Trajectory of Two Neighbors, Actionaid, 2008.

[3] R. S. Shrestha, “Opinion,” West Seti Project. A Nepali Perspective, September 2008.

[4] West Seti Project Document (undated).

[5] B. Gautam and A. Shah, "Law Ministry Opposes West Seti Renewal,” Advises Against New Clauses, Republica, November 2009.

[6] Order of the Supreme Court, September 2009.

[7] B. Sangraula, "China bank to invest \$1b in West Seti," Kantipuronline.com, 2004.

[8] Interim Constitution of Nepal 2063, 2007. 